\title{
Influence of Zakat on Sejahtera Strategic Position and Action
}

\author{
Suhaimi Mhd Sarif \& Dolhadi Zainudin \\ International Islamic University Malaysia \\ Paper to be presented at the $4^{\text {th }}$ International Conference of Zakat (ICONZ) \\ 7-8 October 2020, Surabaya, Indonesia
}

\begin{abstract}
Zakat is religious duty for Muslims. Muslim-owned companies also paid zakat. With religious duty in mind, there is no expectation of worldly rewards. When companies are constantly paid zakat, there is good effect to the companies' performance and competitive advantages. This study postulated that zakat enables companies to gain sejahtera strategic position and action for sustainable performance. The case study on three different companies that paid zakat showed sejahtera position and action. The study uses strategic position and action evaluation (SPACE) Matrix to investigate the influence of zakat on sejahtera strategic position and action. The results of the study showed that zakat has worldly effect.
\end{abstract}

Keywords: Business zakat, Sejahtera, Strategic position, Strategic management

JEL code: $M 14, Z 12$.

\section{INTRODUCTION}

Sejahtera concept has been embedded in Malaysia's education system since 1990s when the sejahtera has been the ultimate outcome of the education system. This education system has been producing human talents with sejahtera since 1990s (Adil, 2019; Hussin, 2020; Hopkins et al, 2020; Nketsia et al, 2020). This implied that the stakeholders in Malaysia have been influenced with sejahtera concept.

Sejahtera is not new in Malaysia. Sejahtera has been in Malaysia's system since the introduction of "Rukun Negara" or National Principles in 1970 (Hamdan, 2011; Malaysia, 2015; Abd Razak, 2020. There are five "pillars" in Rukun Negara, namely belief in God, loyalty to the King and country, supremacy of the constitution, rules of law, and Courtesy and Morality.

The background behind the national principles is due to the sejahtera education. People are able to live harmoniously in multiracial society (Adil, 2019; Abd Razak, 2020). The reasons are due to the ability of the people from different races who are able to live in unity in diversity, able to live in democracy system, able to uphold a caring and just society by ensuring a liberal approach to different traditions. In the meantime, Malaysians are not to neglect the progress of science and technology.

When Muslism are obliged to pay zakat, by default, with the sense of national principles and Sejahtera mindset, Muslims would not have any reason to avoid paying zakat. In fact, they will feel great for paying zakat as a manifestation of their peaceful soul and patriotic behaviour.

Zakat is religious duty for Muslims. Muslim-owned companies also paid zakat. With religious duty in mind, there is no expectation of worldly rewards. When companies are constantly paid zakat, there is good effect to the companies' performance and competitive advantages. This study postulated that zakat enables 
companies to gain sejahtera strategic position and action for sustainable performance. The case study on three different companies that paid zakat showed sejahtera position and action. The study uses strategic position and action evaluation (SPACE) Matrix to investigate the influence of zakat on sejahtera strategic position and action. The results of the study showed that zakat has worldly effect.

\section{LITERATURE REVIEW}

Zakat is Islamic religious duty for Muslims. There is no excuse to avoid paying zakat when it is due. In a capitalist society, there is no legal action taken on Muslims who did not pay zakat. A responsible Muslim will pay zakat when the zakat is due.

Muslims will always pay zakat when it is due. Every Muslim is aware of zakat is a religious obligation (Othman, Yusuff \& Nayan, 2020; Yusfiarto, Setiawan \& Nugraha, 2020). When zakat is regarded as income tax, zakat payers are giving excuses due to negative perceptions and surrounding factors (Azzahra \& Abd Majid, 2020).

Muslim owners of businesses are aware of zakat obligation. There could be dilemma between paying business tax and zakat. Such excuses are no longer valid when zakat accounting has been introduced to the business world (Bakar, 2007). In fact, many companies are paying zakat (Mohamad \& Trakic, 2013). Those who are constantly paying zakat are not just because of religious knowledge, but due to strong faith in executing religious duty. Other factors such as zakat administration leadership, service quality, role model of scholars and vital signs of zakat to the economic development are not the main driver for paying zakat (Azzahra \& Abd Majid, 2020).

Is zakat related to legal and ethical obligations? In economic approach, every business has economic duty to generate profit legally and ethically for the business (Noor Azman \& Bidin, 2015). While perception may be a factor for not paying zakat, most of the cases, the compliance behaviour to pay zakat is due to religious, legal and ethical obligations (Noor Azman \& Bidin, 2015; Othman, Yusuff \& Nayan, 2020).

Some may argue about the literacy inadequacy factor that hinders people to pay zakat. While literacy is essential (Yusfiarto, Setiawan \& Nugraha, 2020), the sense of obligation is far more important (Othman et al, 2020; Azzahra \& Abd Majid, 2020).

\section{METHODOLOGY}

This study uses Strategic Position and Action Evaluation (SPACE) Matrix. The axes of the SPACE Matrix represent two internal dimensions (financial position $[\mathrm{FP}]$ and competitive position [CP]) and two external dimensions (stability position [SP] and industry position [IP]). The SPACE Matrix resulted four quadrants, namely aggressive, competitive, conservative and defensive quadrants.

The use of SPACE Matrix in analysing companies' strategic position provides comprehensive internal-external forces in generating competitive strategies. The strategic position allows for optimisation of corporate, business and functional strategies (Abbasi, Nafari \& Ebrahimi, 2014). The analytical approach enables for dynamism in the strategy generation and selection (Benson \& Henderson, 2005). Any business or organisation can use SPACE analysis (Cross \& Henderson, 2003).

SPACE analysis allows companies to examine competitors' position and action (Radder \& Louw, 1998). The use of SPACE Matrix optimises resources for greater performance and competitive advantage (Sherafat et al, 2013). The 


\section{$4{ }^{\mathrm{TH}}$ INTERNATIONAL CONFERENCE OF ZAKAT PROCEEDINGS}

ISSN: $2655-6251$

analytical evaluation allows for

To generate SPACE Matrix, the oprtimization (Tavana \& Banerjee, 1995).

first step is to produce $\mathrm{X}$ and $\mathrm{Y}$ axis.

Table 1. Calculation of SPACE Matrix

\begin{tabular}{|c|c|}
\hline $\begin{array}{l}\text { Financial Position }(\mathrm{FP}) \\
\text { Rate them as follow: }+1 \text { worst to }+7 \text { best }\end{array}$ & Rating \\
\hline $\begin{array}{l}\text { Return on investment } \\
\text { Leverage } \\
\text { Liquidity } \\
\text { Working capital } \\
\text { Cash flow } \\
\text { Inventory turnover } \\
\text { Earnings per share } \\
\text { Price earnings ratio } \\
\end{array}$ & \\
\hline TOTAL & \\
\hline Average & Total/No of items \\
\hline $\begin{array}{l}\text { Competitive Position (CP) } \\
\text { Rate them as follow: }-1 \text { best to }-7 \text { worst }\end{array}$ & Rating \\
\hline $\begin{array}{l}\text { Market share } \\
\text { Product quality } \\
\text { Product life cycle } \\
\text { Customer loyalty } \\
\text { Capacity utilization } \\
\text { Technology know-how } \\
\text { Control over suppliers and distributors } \\
\end{array}$ & \\
\hline TOTAL & \\
\hline Average & Total/No of items \\
\hline $\begin{array}{l}\text { Stability Position (SP) } \\
\text { Rate them as follow: }-1 \text { best to }-7 \text { worst }\end{array}$ & Rating \\
\hline $\begin{array}{l}\text { Technological changes } \\
\text { Rate of inflation } \\
\text { Demand variability } \\
\text { Price range of competing products } \\
\text { Barriers to entry into market } \\
\text { Competitive pressure } \\
\text { Ease of exit from market } \\
\text { Risk involved in business }\end{array}$ & \\
\hline TOTAL & \\
\hline Average & Total/No of items \\
\hline $\begin{array}{l}\text { Industry Position (IP) } \\
\text { Rate them as follow: }+1 \text { worst to }+7 \text { best }\end{array}$ & Rating \\
\hline $\begin{array}{l}\text { Growth potential } \\
\text { Profit potential } \\
\text { Financial stability } \\
\text { Extent leveraged } \\
\text { Resource utilization } \\
\text { Ease of entry into market } \\
\text { Productivity, capacity utilization } \\
\end{array}$ & \\
\hline TOTAL & \\
\hline Average & Total/No of items \\
\hline $\begin{array}{r}\text { Directional vector coordination: } \mathrm{x} \text { axis } 3.00+(-4.25)=-1.25 \\
\mathrm{y} \text { axis }-3.50+2.50=-1.00\end{array}$ & \\
\hline
\end{tabular}




\section{$4{ }^{\mathrm{TH}}$ INTERNATIONAL CONFERENCE OF ZAKAT PROCEEDINGS \\ ISSN: 2655-6251}

Second step is to draw the SPACE Matrix with directional vector coordination.

At Aggressive Quadrant (upper right) allows an organization to use its internal strengths to (1) take advantage of external opportunities, (2) overcome internal weaknesses, and (3) avoid external threats. The strategies used will enhance performance and competitive advantages.

At Competitive Quadrant (lower right), indicates competitive strategies. Competitive strategies include backward, forward and horizontal integration; market penetration; market development; and product development
At Conservative Quadrant (upper left), which implies staying close to the firm's basic competencies and not taking excessive risks. Conservative strategies most often include market penetration, market development, product development, and related diversification.

At Defensive Quadrant (lower left) suggests the firm should focus on improving internal weaknesses and avoiding external threats. Defensive strategies include retrenchment, divestiture, liquidation, and related diversification.

Figure 1. SPACE Diagram

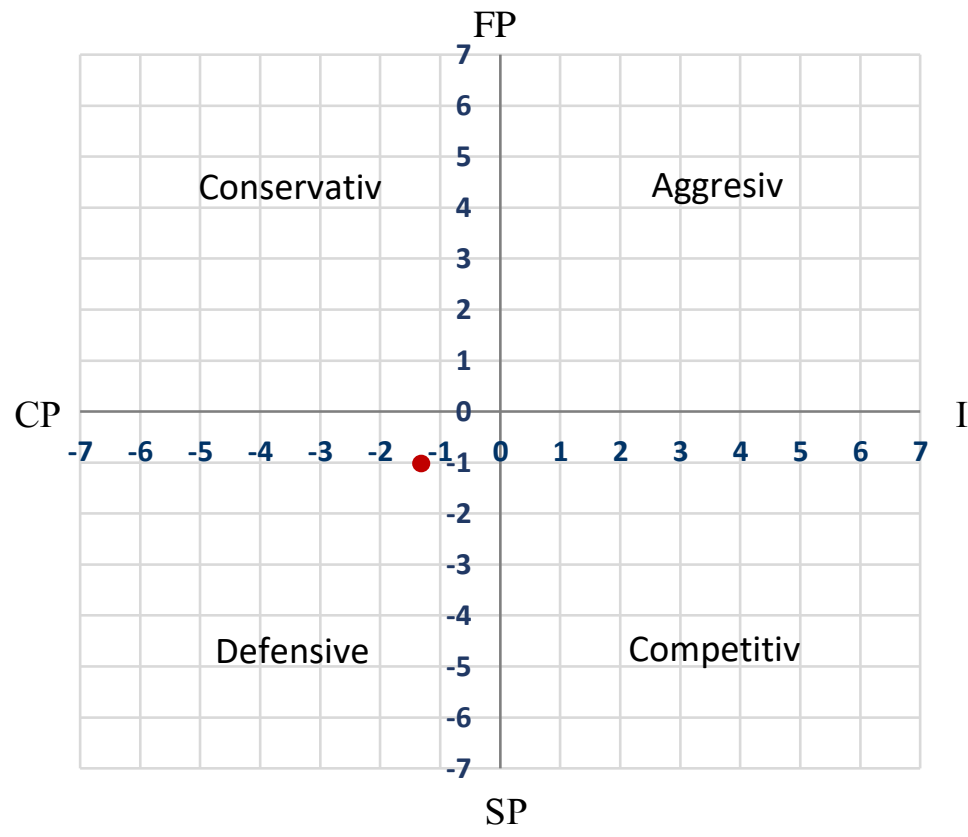

\section{RESULTS AND DISCUSSION}

This section presents the results of SPACE matrix analysis on three companies. The companies are labelled as Company $\mathrm{A}$ and Company B. While Company A is in food manufacturing industry, Company $\mathrm{B}$ is focusing on construction industry.
Company A has been in food manufacturing industry for almost 40 years with ups and downs. Quality products and speed delivery are always expected from Company A. Therefore, Company A is obliged to have continuous improvement and innovation through its research and development. This company paid zakat constantly since its inception. 


\section{$4^{\mathrm{TH}}$ INTERNATIONAL CONFERENCE OF ZAKAT PROCEEDINGS \\ ISSN: $2655-6251$}

Company $\mathrm{B}$ is equally tenured in construction industry for more than five decades. It has gone through challenges in life. However, Company B is never missed to pay business zakat. While zakat is religious obligation, Company $\mathrm{B}$ is also paying business tax. Besides zakat, the company is always practicing philanthropy especially with the workers. This company believes in charity begins at home.

Zakat has significant influence to the performance and competitive position of the companies.

Company $\mathrm{A}$ has moderate rating for financial position, competitive position, stability position and industry position. The moderate rating in financial position implies that Company A has moderate achievement in terms of return on investment, leverage, liquidity, working capital, cash flow, inventory turnover, earnings per share and price earnings ratio. Nevertheless, a moderate situation of competitive position, implies that Company A has relatively better position in terms of market share, product quality, product life cycle, customer loyalty, capacity utilization, technology knowhow, and control over suppliers and distributors.

A moderate rating of Company A's stability position, implied that Company A is moderately stable in terms of technological changes, rate of inflation, demand variability, price range of competing products, barriers to entry into market, competitive pressure, ease of exit from market, and risk involved in business. This situation is supported by the moderate industry position which means Company A has moderate industry position in terms of growth potential, profit potential, financial stability, extent leveraged, resource utilization, ease of entry into market, productivity, and capacity utilization.

The continuous practice of paying zakat has enabled the company to increase net sales to $31.57 \%$ with total assets growth of $9.73 \%$. This situation has improved form least moderate to better moderate position. Table 2 shows the calculation for SPACE matrix of Company A.

Table 2. SPACE Matrix calculation for Company A

\begin{tabular}{lc}
\hline Financial Position (FP) & Rating \\
Rate them as follow : $\mathbf{1}$ worst to $+\mathbf{7}$ best & +4 \\
\hline Net sales revenue increase of $31.57 \%$ in 2017 & +3 \\
\hline Total assets recorded a growth of $9.73 \%$ & +2 \\
\hline Return on Equity of increased $3.82 \%$ & +1 \\
\hline Revenues increased $0.39 \%$ from the previous year & $\mathbf{+ 1 0}$ \\
\hline TOTAL & Rating \\
\hline Competitive Position (CP) & -4 \\
\hline Rate them as follow: $\mathbf{- 1}$ best to $\mathbf{- 7}$ worst & -5 \\
\hline Increased 0.2\% market share in packaged foods & -5 \\
\hline Slow restock - no control over the supply and distribution & -3 \\
\hline No IT Team and no MIS system & $\mathbf{- 1 7}$ \\
\hline Innovative \& high R\&D outcome using latest technologies & $\mathbf{R a t i n g}$ \\
\hline TOTAL & -5 \\
\hline Stability Position (SP) & -2 \\
\hline Rate them as follow: $\mathbf{- 1}$ best to $\mathbf{- 7}$ worst & -4 \\
\hline Increasing demand for FCMG products & -3 \\
\hline Share prices are low to middle range - affordable & $\mathbf{- 1 4}$ \\
\hline Has many competitors especially & \\
\hline $\begin{array}{l}\text { Low barriers to entry - small entrepreneurs can easily sell their } \\
\text { products- small scale operation and process, cheap rent }\end{array}$ & \\
\hline TOTAL &
\end{tabular}




\begin{tabular}{|c|c|}
\hline $\begin{array}{l}\text { Industry Position (IP) } \\
\text { Rate them as follow: }+1 \text { worst to }+7 \text { best }\end{array}$ & Rating \\
\hline Has entered foreign market & +3 \\
\hline Has been in the industry for almost 40 years - good sustainability & +3 \\
\hline Largest food manufacturer in the industry & +3 \\
\hline TOTAL & +9 \\
\hline $\begin{array}{l}\text { FP Average is } 10 / 4=2.50 \\
\text { IP Average is } 9 / 3=3.00 \\
\text { CP Average is }-17 / 4=-4.25 \\
\text { SP Average is }-14 / 4=-3.50\end{array}$ & \\
\hline $\begin{array}{l}\text { Directional vector coordinator: } x \text { axis } 3.00+(-4.25)=-1.25 \\
\\
\begin{array}{ll}\text { Coordinate: }(\mathbf{- 1 . 2 5}, \mathbf{- 1 . 0 0}) & \text { y axis }-3.50+2.50=-1.00\end{array}\end{array}$ & \\
\hline
\end{tabular}

Based on the SPACE diagram, at coordinates $(-1.25,-1.00)$, Company A's directional vector is located at the defensive strategies (below-left quadrant) which suggests that Company A should focus on fixing internal weaknesses and avoiding external threats for it to shift into the aggressive quadrant (upper-right). By continuous to pay zakat and to practice philanthropy, Company A would be able to improve its SPACE position from "defensive" to at least "competitive." Figure 2 shows the SPACE diagram for Company A.

Figure 2. SPACE Diagram for Company A

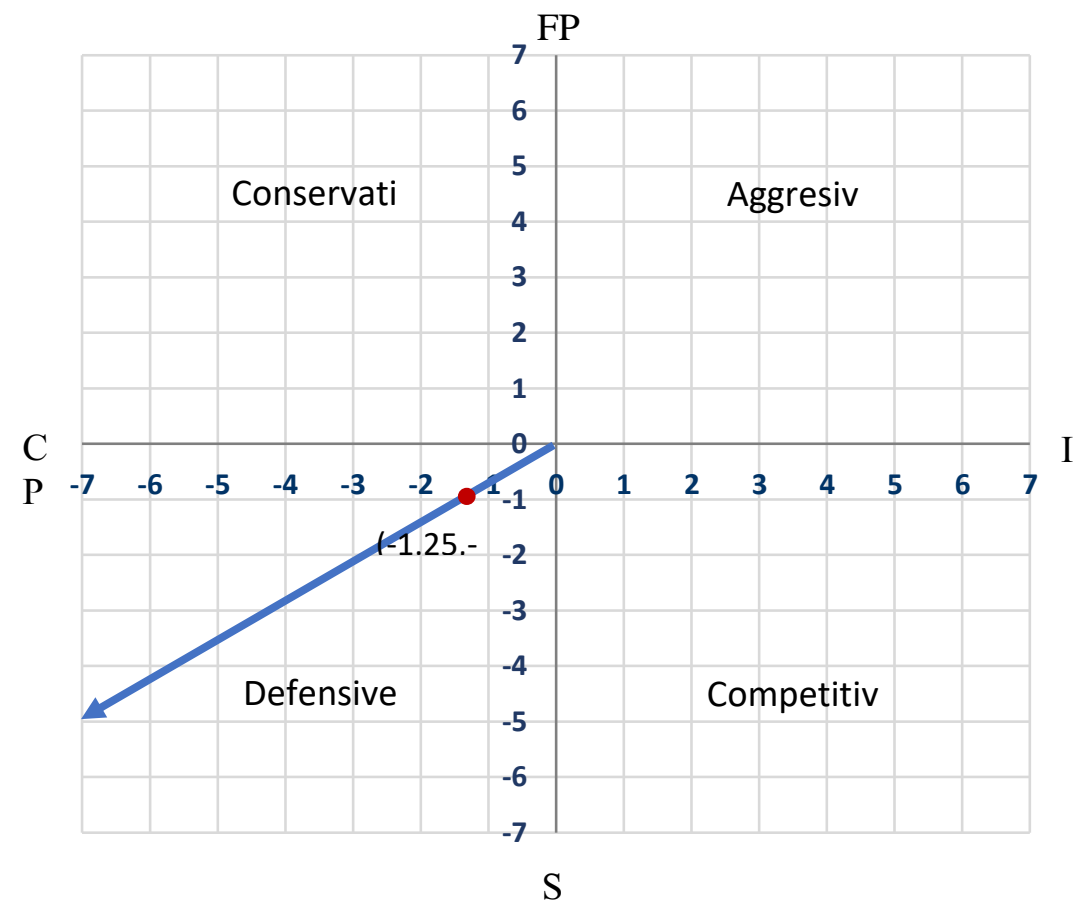

Company B's SPACE situation is slightly better than Company A. As a construction company, it faces a lot of challenges due to the environment uncertainty and the global pandemic. Company B has higher moderate rating for financial position, competitive position, stability position and industry position.

Company B has slightly higher moderate rating for financial position, competitive position, stability position and 
industry position. The moderate rating in financial position implies that Company B has stronger moderate achievement in terms of return on investment, leverage, liquidity, working capital, cash flow, inventory turnover, earnings per share and price earnings ratio. Nevertheless, a moderate situation of competitive position, implies that Company B has relatively far better position in terms of market share, product quality, product life cycle, customer loyalty, capacity utilization, technology know-how, and control over suppliers and distributors.

A moderate rating of Company B's stability position, implied that Company B is moderately stable in terms of technological changes, rate of inflation, demand variability, price range of competing products, barriers to entry into market, competitive pressure, ease of exit from market, and risk involved in business. This situation is supported by the moderate industry position which means Company B has moderate industry position in terms of growth potential, profit potential, financial stability, extent leveraged, resource utilization, ease of entry into market, productivity, and capacity utilization.

The continuous practice of paying zakat has enabled the company to reach higher moderate situation. Table 3 shows the calculation of SPACE Matrix for Company B.

Table 3. SPACE Matrix Calculation for Company B

\begin{tabular}{ll}
\hline \multicolumn{1}{c}{ SPACE MATRIX } & \\
\hline Financial Position (Y-Axis +ve) & $\mathbf{+ 7}$ Best, +1 Worst \\
\hline Return on Investment slowly increasing & +3 \\
Diminishing trend of leverage since the last five years & +4 \\
Promising upward trend in Inventory turnover & +5 \\
\hline TOTAL & +12 \\
\hline Average & $+12 / 3=+4$ \\
\hline Industry Position (X-Axis +ve) & $+\mathbf{+ 7}$ Best, +1 Worst \\
\hline Growth Potential Expected to be Moderate & +3 \\
Barriers to Entry Into Market Is Quite Tight Since Need Large & +4 \\
Capital & \\
Profit Potential Expected to be Mediocre Considering Competitive & +3 \\
Environment Among Competitors & \\
\hline TOTAL & +10 \\
\hline Average & $+10 / 3=+3.33$ \\
\hline Stability Position (Y-Axis -ve) & $\mathbf{( - 1 ) ~ B e s t , ~ ( - 7 ) ~ W o r s t ~}$ \\
\hline Pressure Among Competitors Is Moderate & -4 \\
Level of Technological Change Is Quite Steady & -2 \\
Volatility of Demand Is Relatively Stable & -2 \\
\hline TOTAL & -8 \\
\hline Average & $-8 / 3=-2.67$ \\
\hline Competitive Position (X-Axis -ve) & $\mathbf{( - 1 ) ~ B e s t , ~ ( - 7 ) ~ W o r s t ~}$ \\
\hline Quite advance in Technological know-how & -3 \\
Product life cycle is expected to be in growth stage for a quite long & -4 \\
time & -4 \\
Moderate power source utilization & -11 \\
\hline TOTAL & $-11 / 3=-3.67$ \\
\hline Average & -0.34 \\
\hline X axis = IP+CP (3.33 + (-3.67)) & 1.33 \\
Y axis = FP+SP (4+(-2.67)) & \\
\hline
\end{tabular}




\section{$4^{\mathrm{TH}}$ INTERNATIONAL CONFERENCE OF ZAKAT PROCEEDINGS \\ ISSN: $2655-6251$}

Based on the SPACE diagram, at coordinates $(-0.34,+1.33)$, Company B's directional vector is located at the conservative strategies (upper-left quadrant) which suggests that Company B should focus on fixing internal weaknesses and avoiding external threats for it to shift into the aggressive quadrant (upper-right). By continuous to pay zakat and to practice philanthropy, Company B would be able to improve its SPACE position from "conservative" to "aggressive." Figure 3 shows the SPACE diagram for Company B.

Figure 3. SPACE Diagram for Company B

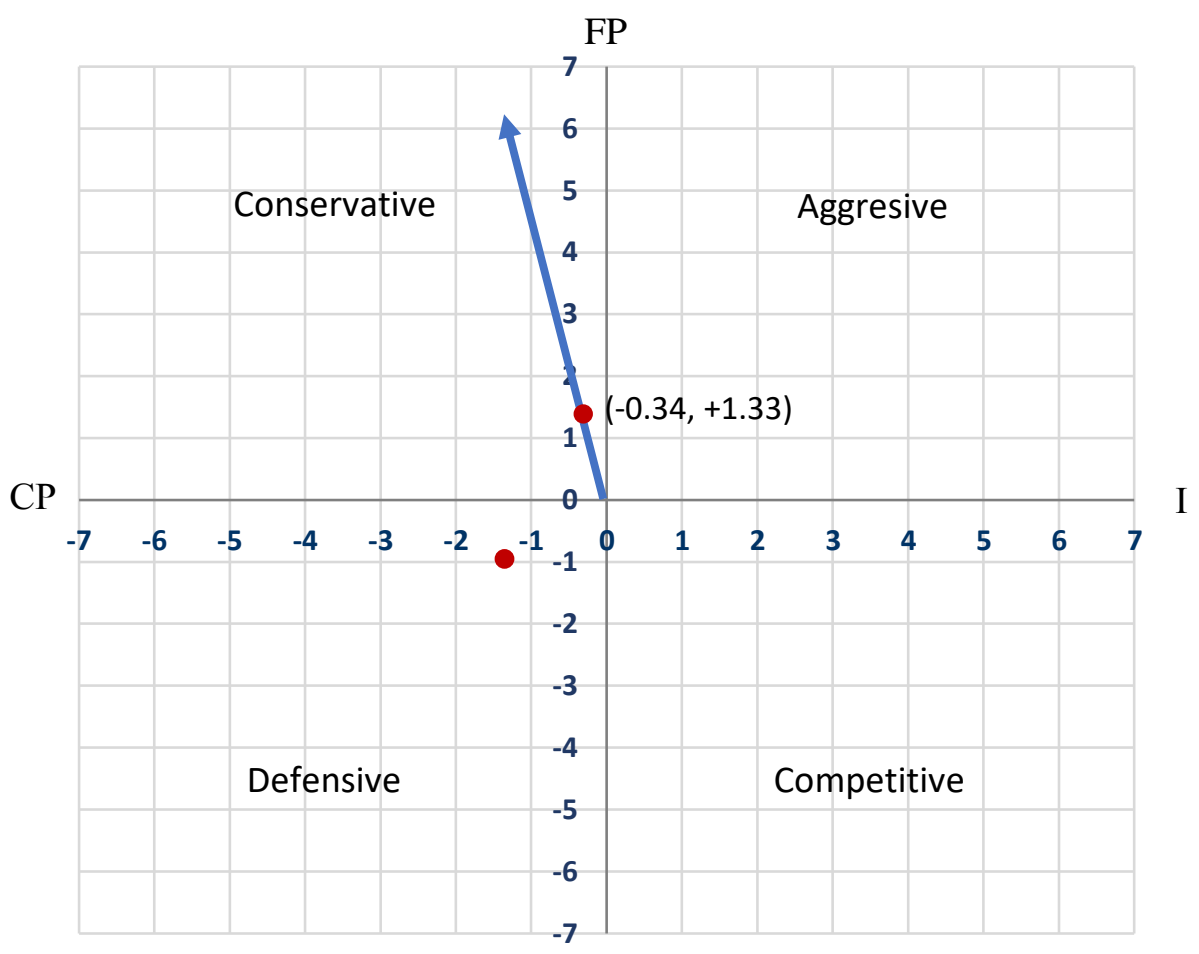

Company A and Company B have been moderate industry position can be related to its compliance behaviour to pay zakat is due to its legal and ethical obligations (Noor Azman \& Bidin, 2015; Othman, Yusuff \& Nayan, 2020). In the meantime, Company A has no difficulties to do so with the presence of zakat accounting systems (Bakar, 2007; Mohamad \& Trakic, 2013). The use of SPACE analysis has proven Company A has been scientific in the business approach (Abbasi, Nafari \& Ebrahimi, 2014) in the strategy generation and selection (Benson \& Henderson, 2005).
This study postulated that zakat has influence on strategic position of companies. While zakat is always religious duty for Muslims, companies are constantly paid zakat received good effect on performance and competitive advantages. The strategic position and action evaluation (SPACE) Matrix has shown the influence of zakat on sejahtera strategic position and action in terms of financial position, competitive position, stability position and industry position.

\section{REFERENCES}

Abbasi, A., Nafari, R., \& Ebrahimi, A. (2014). Investigating the strategic

\section{CONCLUSION}


position and representing a suitable marketing strategy using SPACE Matrix in Sepahan Battery Company. Asian Journal of Research in Marketing, 3(6), 72-86.

Abd Razak, M. R. (2020). Pembinaan Negara Bangsa Malaysia: Peranan Pendidikan Sejarah dan Dasar Pendidikan Kebangsaan. Jebat: Malaysian Journal of History, Politics \& Strategic Studies, 36.

Adil, M. A. M. (2019). Rukun Negara as the Preamble to the Federal Constitution. Islam and Civilisational Renewal ICR Journal, 10(1), 118-120.

Azzahra, F., \& Abd Majid, M. S. (2020). What drives muzakki to pay zakat at Baitul Mal?. Shirkah: Journal of Economics and Business, 5(1), 2752.

Bakar, N. (2007). A zakat accounting standard (ZAS) for Malaysian companies. American Journal of Islamic Social Sciences, 24(4), 7476.

Benson, A. M., \& Henderson, S. (2005). Strategic characteristics of sport and recreation provision: an application of SPACE analysis. Managing Leisure, 10(4), 251-267.

Cross, J., \& Henderson, S. (2003). Strategic challenges in the football business: a SPACE analysis. Strategic Change, 12(8), 409-420.

David, F. R. (1986). The strategic planning matrix - a quantitative approach. Long Range Planning, 19(5), 102107.

Hamdan, A. R. (2011). Falsafah dan pemikiran pendidikan. Penerbit UTM Press.

Hopkins, C. A., Michelsen, G., Salīte, I., Siegmund, A., Wagner, D. A., Yokoi, A., ... \& Tilleczek, K. (2020). Sustainability as a purpose on the new path of learning for the future. Humanistic futures of learning, 58.

Hussin, S. (2020, August). Identity Through Culture and Arts Education. In 1st International Conference on Language, Literature, and Arts Education (ICLLAE 2019) (pp. 455459). Atlantis Press.

Malaysia, K. P. (2015). Pelan Pembangunan Pendidikan Malaysia 2015-2025 (Pendidikan Tinggi). Putrajaya, Malaysia: Kementerian Pendidikan Malaysia.

Mohamad, T. A. H., \& Trakic, A. (2013). Critical appraisal of companies' obligations to pay Zakat in the Malaysian context. International Company and Commercial Law Review, 24(10), 375-381.

Nketsia, W., Opoku, M. P., Saloviita, T., \& Tracey, D. (2020). Teacher Educators' and Teacher Trainees' Perspective on Teacher Training for Sustainable Development. Journal of Teacher Education for Sustainability, 22(1), 49-65.

Noor Azman, F. M., \& Bidin, Z. (2015). Factors influencing zakat compliance behavior on saving. International Journal of Business and Social Research, 5(1), 118-128.

Othman, Y., Yusuff, M. S. S., \& Nayan, M. A. (2020). The influence of perception towards legal and ethical obligations on compliance behavior of income zakat in Kedah. International Journal of Advanced Research in Islamic and Humanities, 2(2), 1-6.

Radder, L., \& Louw, L. (1998). The SPACE matrix: A tool for calibrating competition. Long Range Planning, 31(4), 549-559.

Sherafat, A., Yavari, K., Mohammad, S., Davoodi, S., \& Bozorgzadeh, N. (2013). The application of Strategic Position \& Action Evaluation 
(SPACE) matrix in the organizational goals and strategies development. Journal of Applied Sciences Research, 9(4), 2666-2673.

Tavana, M., \& Banerjee, S. (1995). Evaluating strategic alternatives: an analytical model. Computers \& Operations Research, 22(7), 731743.

Yusfiarto, R., Setiawan, A., \& Nugraha, S. S. (2020). Literacy and intention to pay zakat. International Journal of Zakat, 5(1), 15-27.

Suhaimi Mhd Sarif

Associate Professor, Department of Business Administration Kulliyyah of Economics and Management Sciences, International Islamic University Malaysia suhaimims@iium.edu.my

Dolhadi Zainudin Assistant Professor

Kulliyyah of Economics and Management Sciences, International Islamic University Malaysia

dolhadi@iium.edu.my 